БАРЫКИНА А. И.

ПРЕДСТАВЛЕНИЯ О ПОНЯТИИ «СЛУЖЕНИЕ» ПРЕДСТАВИТЕЛЕЙ РАЗЛИЧНЫХ ПРОФЕССИОНАЛЬНЫХ ГРУПП

Российский психологИчЕский жУРнАл, 2020, Т. 17, № 3, 44-59. doi: 10.21702/rpj.2020.3.4

пСихолОГИЯ ТРУДА

УдК 159.9.072 doi: $\underline{10.21702 / r p j .2020 .3 .4}$

Оригинальная научная статья

\title{
Представления о понятии «служение» представителей различных профессиональных групп
}

\author{
Анастасия И. Барыкина \\ Нижегородский государственный университет им. Н. И. Лобачевского, г. Нижний Новгород, Российская \\ Федерация \\ E-mail: aicher2466@gmail.com \\ ORCID ID: https://orcid.org/0000-0003-1125-6143
}

\begin{abstract}
Аннотация
Введение. В статье преАставлены результаты исслеАования особенностей преАставлений о понятии «служение» преАставителей различных профрессиональных групп: госслужащих, военнослужащих национальной гвардии Российской Фелерации, пожарныхи спасателей Министерства Российской Фелерации по Аелам гражАанской обороны, чрезвычайным

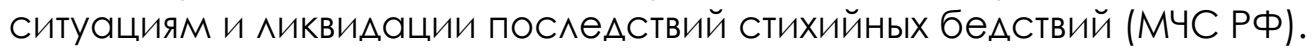

Метолы. Использован метол экспертных оценок, направленный на получение инорормации (мнений экспертов) и позволяющий восполнить и упоряАочить свеАения о служении. В качестве экспертов выступили специалисты, чья Аеятельность (служба, служение) направ^ена на благо страны и общества: госслужащие, военнослужащие национальной гвардии РФ, пожарные и спасатели МЧС. МетоА контент-анализа позволи^ выполнить качественный и количественный анализ солержания ответов экспертов о понятии «служение».

Результаты и их обсужАение. Вылеленные Аингвистические еАиницы анализа ответов экспертов объединены в 5 контент-аналитических категорий: «отношение к труду», «исполнение гражАанского, служебного Аолга», «помощь АюАям», «черты ^ичности», «богослужение». В преАставлении госслужащих служение относится к категориям «помощь АЮАям», «отношение к труду», «исполнение гражАанского, служебного Аолга». Военнослужащие характеризуют служение категориями «исполнение гражАанского, служебного Аолга» и «отношение к труду». Категории «черты личности», «помощь АюАям», «отношение к труАу», «исполнение гражАанского, служебного Аолга» являются наиболее значимыми в представлении пожарных и спасателей МЧС о понятии «служение». Все эксперты представ^яют служение как профрессиональную Аеятельность, направленную на оказание помощи ^юдям и исполнение гражданского, служебного Аолга, обусловленную эмоционально-ценностным отношением к труду. Различия в понимании служения представителями различных профессиональных групп обусловлены специфрикой и солержанием их профессиональной деятельности. Новизна результатов исслеАования заключается в расширении знаний о служении как психологическом френомене и в возможности их использования в психологическом и мотивационном обеспечении профрессиональной Аеятельности специалистов.
\end{abstract}

\section{КАючевые слова}

служение, понимание служения, представление о служении, продрессиональные группы, эксперты, лингвистические единицы, госслужащие, военнослужащие, пожарные, спасатели 
БАРЫКИНА А. И.

ПРЕДСТАВЛЕНИЯ О ПОНЯТИИ «СЛУЖЕНИЕ» ПРЕДСТАВИТЕЛЕЙ РАЗЛИЧНЫХ ПРОФЕССИОНАЛЬНЫХ ГРУПП

РосСИЙСКИЙ пСИХологИЧЕСКИЙ ЖУРнАл, 2020, Т. 17, № 3, 44-59. doi: 10.21702/rpj.2020.3.4

пСИхолОгИя тРУДА

\section{Основные положения}

> в преАставлениях о понятии «служение» преАставителей различных профрессиональных групп имеются схолства и различия, обусловленные спецификой и солержанием их профеессиональной Аеятельности;

$\checkmark$ категории «отношение к труду», «исполнение гражАанского, служебного Аолга» и «помощь ^ЮАям» явАяются основными в преАставлении эКспертов о понятии служения;

$\checkmark$ госслужащие, военнослужащие, пожарные и спасатели МЧС представляют служение как продрессиональную Аеятельность, обусловленную эмоционально-ценностным, положительным к ней отношением, направленную на исполнение гражданского, служебного Аолга и помощь АюАям ^ичностью, обладающей опреАеленными качествами;

$\checkmark$ исследование социальных представлений о служении расширяет знания о служении как психологическом френомене.

\section{Для цитирования}

Барыкина, А. И. (2020). Представления о понятии «служение» представителей различных профессиональных групп. Российский психологический журнал, 17(3), 44-59. doi: 10.21702/rpj.2020.3.4

Дата получения рукописи: 02.06.2020

Дата окончания рецензирования: 03.08.2020

Дата принятия к публикации: 09.08.2020

\section{Введение}

Актуальность исследования служения обусловлена ограниченностью ресурсов и эффективности воздействия монетарной мотивации сотрудников в социально значимых профессиональных сферах и востребованностью поиска методов нематериальной мотивации профессиональной деятельности, в частности на основе актуализации мотива служения.

Обзор литературы показал недостаточность разработанности теоретических и практических аспектов проблемы служения. В отечественных теоретических научных исследованиях служение преимущественно рассматривается представителями религиоведческого, исторического, философского знания в контексте традиций отечественной благотворительности и практики социального служения (Антонова, 2009; Дойникова, 2006; Зубанова, 2012, 2013; Зубанова, Степанов, Патюлина и Рузанова, 2013; Краснобаева, 2013; Левченко и Черкасова, 2013; Степанов, 2012; Субаева, 2004; Устиненко, 2008; и др.). Зарубежный опыт также говорит о распространенности социального служения преимущественно такими некоммерческими объединениями, как People Serving People Foundation (https://www. pspfoundation. org/), People Serving People (https://www. peopleservingpeople. org/) и частными лицами (McNeely, n.d.).

Также известны работы, отражающие феномен служения профессии представителей различных сфер профессиональной деятельности: библиотекарей, ученых, лесничих, поэтов, юристов, музыкантов, медработников, агрономов и др. (Золотухина и Смирнова, 2013; Стуков, Осяева и Шашкина, 2013; Кулик, 2017; Селиховкин, 2009; Решетняк, 2017; Панюшкин, 1997; Карпов, 2013; Blozen, 2018; Hurst-Wahl, 2014; Khan, 2017; Langsley, 1989; Sims \& Openshaw, 1980). В работе Malik, Yamamoto, Souares, Malik, \& Sauerborn (2010) показано, что внутренние и социокультурные факторы, такие как служение, являются важными мотивами профессиональной деятельности врачей. 
БАРЫКИНА А. И.

ПРЕДСТАВЛЕНИЯ О ПОНЯТИИ «СЛУЖЕНИЕ» ПРЕДСТАВИТЕЛЕЙ РАЗЛИЧНЫХ ПРОФЕССИОНАЛЬНЫХ ГРУПП

Российский психологИчЕский жУРнАл, 2020, Т. 17, № 3, 44-59. doi: 10.21702/rpj.2020.3.4

пСихолОГИЯ ТРУДА

Актуальность изучения социальных представлений о служении обусловлена сочетанием популярности понятия «служение» в общеупотребительной практике россиян с многообразием и неоднозначностью определений понятия служения, с неустойчивостью содержательного восприятия и представлений о данном понятии, а также отсутствием научного психологического взгляда на этот феномен (Barykina \& Shutova, 2018). Исследование социальных представлений о служении может открыть новые возможности и для изучения самого феномена служения, и для прогнозирования процессов, происходящих в ценностно-смысловой сфере различных профессиональных групп и общества в целом.

Теория социальных представлений Московичи (1995) предполагает, что социальные представления - это любые формы убеждений, идеологических взглядов, знаний членов социальной группы по отношению к изменяющейся жизни. Социальные представления являются потенциально осознаваемыми, широко разделяются членами определенной социально-культурной группы, выполняют особую роль в поддержании и регуляции внутригрупповых отношений (Мустафина, 2012). Работа в русле концепции социальных представлений предоставляет возможности изучить то, как наши современники понимают служение, и сформулировать авторское определение этого понятия.

На сегодняшний день имеется недостаточное количество психологических исследований, посвященных проблематике служения как психологического феномена, что подчеркивает актуальность настоящей работы.

\section{Цель исследования}

В этой связи нами было проведено исследование с целью выявления особенностей представлений о служении представителей различных профессиональных групп: госслужащих, военнослужащих национальной гвардии Российской Федерации (далее - военнослужащие), пожарных и спасателей МЧС.

\section{Методы}

Исследование осуществлялось с применением метода экспертных оценок, заключающегося в организации работы со специалистами-экспертами, направленной на получение информации (мнений экспертов), выраженной в количественной и/или качественной форме, ее обработку, анализ и обобщение результатов в соответствии с поставленной целью. Метод экспертных оценок, позволяющий в сочетании с другими математико-статистическими методами упорядочить информацию об исследуемом объекте, выявить его специфику, получил распространение как в отечественной (Артюхов и др., 2012; Карпова, Сочивко и Пастушеня, 2019; Максименкова, 2018), так и в зарубежной психологической науке (Benini et al., 2017; Neal \& Grisso, 2014; Zondervan-Zwijnenburg, van de Schoot-Hubeek, Lek, Hoijtink, \& van de Schoot, 2017).

\section{Участники исследования}

При формировании группы экспертов были соблюдены требования к их количественному составу и качественной однородности. В качестве экспертов были приглашены наиболее квалифицированные представители профессиональных групп с опытом работы не менее 5 лет. Были сформированы 6 групп экспертов, состоящих из специалистов, чья деятельность предполагает работу (службу, служение) на благо страны и общества: 
БАРЫКИНА А. И.

ПРЕДСТАВЛЕНИЯ О ПОНЯТИИ «СЛУЖЕНИЕ» ПРЕДСТАВИТЕЛЕЙ РАЗЛИЧНЫХ ПРОФЕССИОНАЛЬНЫХ ГРУПП

РосСИЙСКИй пСИХологИЧЕСКИЙ ЖУРнАл, 2020, Т. 17, № 3, 44-59. doi: 10.21702/rpj.2020.3.4

ПСИхОЛОГИЯ ТРУДА

1. Госслужащие - 30 экспертов (из них $67 \%$ женщин и $33 \%$ мужчин; образование высшее и среднее специальное; средний стаж 12 лет).

2. Военнослужащие - 28 экспертов (из них $11 \%$ женщин и $89 \%$ мужчин; образование высшее; средний стаж 24 года).

3. Пожарные и спасатели МЧС - 32 эксперта (из них 3 \% женщин и 97 \% мужчин; образование высшее; средний стаж 17 лет).

Общее число экспертов составило 90 человек. Возраст экспертов от 24 до 59 лет (ср. знач.42,7, станд. отклон. = 9,98; $27 \%$ женщин и 73 \% мужчин).

\section{Процедура проведения исследования}

Карту экспертного опроса (анкету) разрабатывали с учетом требований к качеству составления, предусмотрев наличие инструкции, в которой обозначены цель проведения экспертизы и порядок работы с анкетой.

В карту экспертного опроса был включен вопрос открытого типа: «Под "служением" я понимаю...». Вопрос направлен на исследование представлений о понятии «служение».

Процедура проведения опроса являлась классической: каждый эксперт после ознакомления с инструкцией самостоятельно заполнял карту экспертной оценки, ставил дату и подпись. Подписью эксперты подтверждали свое согласие на участие в опросе и хранение данных.

При проведении исследования незначительная часть экспертов (2 человека, 1,08\%) испытывала затруднение в определении понятия служения, но большинство участников исследования чутко уловили смысл задания и дали полные ответы на вопросы.

Всего было проанализировано 90 карт экспертного опроса. Все анкеты были признаны действительными.

Для анализа ответов экспертов на вопросы карты экспертного опроса были применены метод контент-анализа (от англ. contents - содержание) и методы математической статистически с использованием $\chi^{2}$ Пирсона.

Система категоризации, положенная в основу метода контент-анализа, позволила выполнить качественный и количественный анализ содержания ответов экспертов на вопросы анкеты (Денисенко и Чеботарева, 2008).

Проведенное исследование можно назвать способом «извлечения смысловых тенденций из размытого экспертного знания» (Базаров, Ерофеев и Шмелев, 2014). Признавая обусловленность ответов экспертов профессиональной направленностью, в данном исследовании предполагалось описать представления экспертов о понятии служения как социальное творчество, обладающее потенциалом отражения профессиональной культуры.

\section{Этапы исследования}

При проведении контент-анализа ответов экспертов были соблюдены требуемые этапы:

1. Определена система контент-аналитических категорий (категорий анализа) - наиболее общие, ключевые понятия, соответствующие исследовательской задаче.

2. Выделены единицы анализа - лингвистические единицы (элементы содержания текста).

3. Подсчитаны частоты встречаемости лингвистических единиц, относящихся к той или иной контент-аналитической категории анализа (табл. 1). Последний этап предусматривал обобщение полученных результатов и формулирование выводов по результатам исследования (Байбородова и Чернявская, 2018). 
БАРЫКИНА А. И.

ПРЕДСТАВЛЕНИЯ О ПОНЯТИИ «СЛУЖЕНИЕ» ПРЕДСТАВИТЕЛЕЙ РАЗЛИЧНЫХ ПРОФЕССИОНАЛЬНЫХ ГРУПП

Российский психологИчЕский жУРнАл, 2020, Т. 17, № 3, 44-59. doi: 10.21702/rpj.2020.3.4

пСИхолОГИя ТРУДА

Выделенные 98 лингвистических единиц анализа (элементы содержания текста) объединены в 5 контент-аналитических категорий (табл. 1):

1) отношение к труду (25 лингвистических единиц, $26 \%$ );

2) исполнение гражданского, служебного долга (27 лингвистических единиц, $27 \%$ );

3) помощь людям (25 лингвистических единиц, $26 \%$ );

4) черты личности (18 лингвистических единиц, $18 \%)$;

5) богослужение (3 лингвистических единицы, 3 \%).

\section{Результаты и их обсуждение}

Полученные результаты и анализ представлений о понятии «служение» экспертов - представителей различных профессиональных групп, а именно госслужащих, военнослужащих, пожарных и спасателей МЧС, представлены в таблице 1 и на рисунке 1.

\begin{tabular}{|c|c|c|c|c|c|c|c|c|c|c|c|}
\hline $\begin{array}{l}\text { Таблица } 1 \\
\text { Частота ^ингвис } \\
\text { по контент-анал }\end{array}$ & $\begin{array}{l}\text { 1ческих еА } \\
\text { 1тическим }\end{array}$ & $\begin{array}{l}\text { ниц в } \\
\text { атего }\end{array}$ & $\begin{array}{l}\text { Tвет } \\
\text { ИяМ }\end{array}$ & ЭKCГ & $O B O$ & Няти & C^yЖ & ия и & ICח & $\Delta e \wedge e$ & $4 x$ \\
\hline \multirow{5}{*}{ Эксперты, чел. } & & \multicolumn{10}{|c|}{ Контент-аналитические категории анализа } \\
\hline & Частота & \multirow{3}{*}{\multicolumn{2}{|c|}{$\begin{array}{l}\text { Отно- } \\
\text { шение } \\
\text { к труду }\end{array}$}} & \multirow{3}{*}{\multicolumn{2}{|c|}{$\begin{array}{l}\frac{\text { Исполнение }}{\frac{\text { гражАан- }}{\text { ского, }}} \\
\frac{\text { служебного }}{\unrhd \text { олга }}\end{array}$}} & \multirow{3}{*}{\multicolumn{2}{|c|}{$\frac{\text { Помощь }}{\underline{\Lambda \triangle \triangle 9 M}}$}} & \multirow{3}{*}{\multicolumn{2}{|c|}{$\begin{array}{c}\text { Черты } \\
\text { Аичности }\end{array}$}} & \multirow{3}{*}{\multicolumn{2}{|c|}{$\begin{array}{c}\text { Бого- } \\
\text { служение }\end{array}$}} \\
\hline & 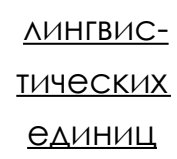 & & & & & & & & & & \\
\hline & & & & & & & & & & & \\
\hline & es. & eA. & $\%$ & eA. & $\%$ & es. & $\%$ & eA. & $\%$ & eA. & $\%$ \\
\hline $\begin{array}{l}\text { Госслужащие, } \\
\mathrm{n}=30\end{array}$ & 28 & 9 & 32 & 6 & 22 & 11 & 39 & 2 & 7 & 0 & 0 \\
\hline Военно- & & & & & & & & & & & \\
\hline $\begin{array}{l}\text { служащие, } \\
n=28\end{array}$ & 31 & 9 & 29 & 14 & 45 & 5 & 16 & 2 & 7 & 1 & 3 \\
\hline Пожарные & & & & & & & & & & & \\
\hline $\begin{array}{l}\text { и спасатели } \\
\text { МчС, } n=32\end{array}$ & 39 & 7 & 18 & 7 & 18 & 9 & 23 & 14 & 36 & 2 & 5 \\
\hline Сумма частот & 98 & 25 & 26 & 27 & 28 & 25 & 26 & 18 & 18 & 3 & 3 \\
\hline
\end{tabular}


БАРЫКИНА А. И.

ПРЕДСТАВЛЕНИЯ О ПОНЯТИИ «СЛУЖЕНИЕ» ПРЕДСТАВИТЕЛЕЙ РАЗЛИЧНЫХ ПРОФЕССИОНАЛЬНЫХ ГРУПП

РосСИЙСКИй пСИХолоГИЧЕСКИй ЖУРнАл, 2020, Т. 17, № 3, 44-59. doi: 10.21702/rpj.2020.3.4

ПСИХОЛОГИЯ ТРУДА

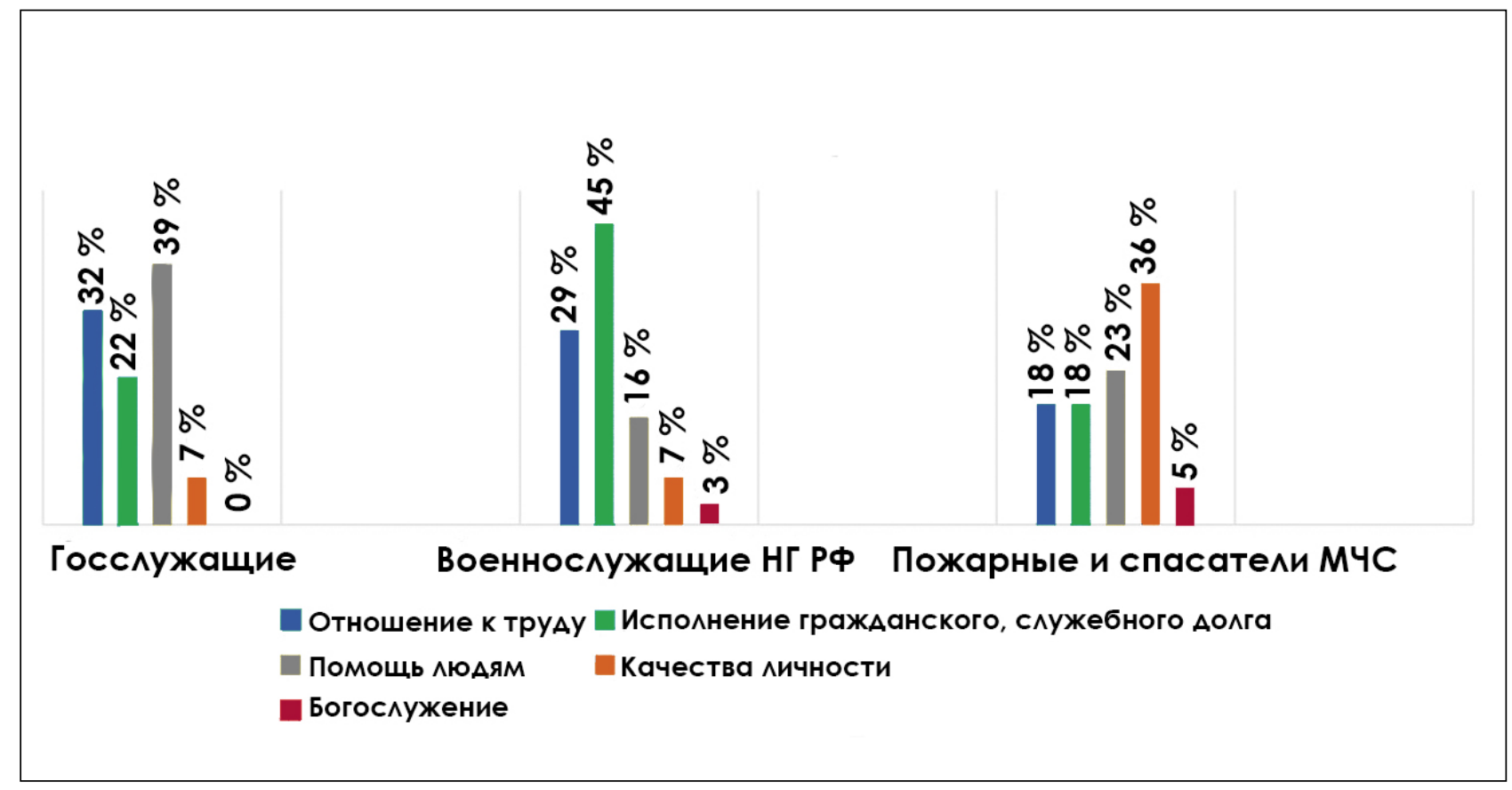

Рисунок 1. Частота встречаемости Аингвистических еАиниц в ответах экспертов о понимании служения и распределение их по контент-аналитическим категориям, \%

Анализ показал, что частота встречаемости лингвистических единиц (элементов содержания текста) (табл. 1) в категории «отношение к труду» составляет 25 единиц, или $26 \%$ от общего количества ответов. К ней отнесены следующие лингвистические единицы: «доброкачественно выполнять свое дело»; «посвящение себя какой-либо цели, идее»; «посвящать себя деятельности»; «качественно выполнять поставленные задачи»; «добросовестно, ответственно относиться к работе»; «профессиональная отдача личности»; «любимая работа»; «честь и достоинство профессии»; "выполнение приказов»; "подчиняться по собственной воле другому человеку»; «беспрекословно подчиняться приказам или указаниям»; «подчинение»; «дисциплина»; «порядок»; «деятельность, реализующая нравственные ценности»; «следовать этическим и правовым нормам» и др.

Для категории «исполнение гражданского, служебного долга» (частота встречаемости 27 лингвистических единиц, или $27 \%$ ) были выбраны следующие лингвистические единицы анализа: «отдавать долг Родине»; «отдавать свой гражданский долг государству»; «выполнять долг перед кем-либо»; «выполнять свой долг»; «исполнять гражданский, государственный, воинский, служебный долг Родине, Отечеству»; «долг перед страной»; «определенный долг государству и обществу»; "защищать Родину»; "верность Родине»; "служить Отечеству»; «отдавать себя, все свои силы»; «не щадя себя, положить души за Отечество»; «не щадя своей жизни, положить души на алтарь Отечества»; "работать во благо Родины»; "работа на государство»; «работать на благо Родины, себя и своей семьи»; «воинский долг»; «воинская служба»; «служба в армии»; «работа в опасных условиях»; «выполнять поставленные мне задачи от руководства»; «выполнять служебно-боевые задачи»; "выполнять все поставленные задачи» и др. 
БАРЫКИНА А. И.

ПРЕДСТАВЛЕНИЯ О ПОНЯТИИ «СЛУЖЕНИЕ» ПРЕДСТАВИТЕЛЕЙ РАЗЛИЧНЫХ ПРОФЕССИОНАЛЬНЫХ ГРУПП

Российский психологИчЕский жУРнАл, 2020, Т. 17, № 3, 44-59. doi: 10.21702/rpj.2020.3.4

Психология трудА

К категории «помощь людям» были отнесены 25 лингвистических единиц анализа, или 26 \% из числа ответов: «помогать, оказывать помощь людям»; «делать добро»; "отдавать людям»; "улучшать жизни людей»; «приносить пользу»; "работать для людей»; «защищать людей»; "служить народу»; "соблюдать интересы человека»; «действовать на благо общества»; "участие в улучшении условий жизни людей»; "быть ответственным за жизнь и спокойствие других»; "уважать людей, которым служу»; "безвозмездная самоотверженная помощь» и др.

К категории «черты личности» (18\%, или 18 лингвистических единиц) были отнесены названные экспертами в качестве понимания служения черты личности человека: ответственность, честность, честь, совесть, достоинство, гордость, неподкупность, профессионализм, патриотизм и др.

Отдельно была выделена категория «богослужение», в которую вошли высказывания «служение Богу», "процесс служения церкви», «богослужение, храм». То есть 3 лингвистические единицы, или $3 \%$ от общего количества ответов экспертов.

\section{Анализ представлений о понятии «служение» государственных служащих}

При анализе представлений о понятии «служение» государственных служащих $(\mathrm{n}=30)$ выявлена лингвистическая иерархия, доминирующую позицию в которой занимали ответы из нескольких категорий: «помощь людям» (39\% высказываний), «отношение к труду» (32\% высказываний) и «исполнение гражданского, служебного долга» (22\% высказываний). Самыми редкими оказались высказывания, отнесенные к категории «черты личности» (7\% высказываний), а лингвистические единицы из категории «богослужение» в лексиконе экспертов отсутствовали вовсе (0\%) (табл. 1; рис. 1).

Анализ выявил статистически значимые различия по критерию $\chi^{2}$ Пирсона $\left(\chi^{2}=5,455\right.$; $\mathrm{p}<0,05)$ между категориями «помощь людям», «отношение к труду», «исполнение гражданского, служебного долга» (условно отнесены к 1-му уровню) и категорией «черты личности» (условно отнесена ко 2-му уровню) (табл. 2). Таким образом, к 1-му уровню отнесены категории, с которыми госслужащие более всего соотносят понятие «служение», а ко 2-му уровню - менее всего. Между категориями внутри уровней статистически значимые различия отсутствуют (табл. 2).

\begin{tabular}{|c|c|}
\hline $\begin{array}{l}\text { Таблица } 2 \\
\text { Структура представлений госслужащих о поняти }\end{array}$ & мужение» $(n=30)$ \\
\hline Уровни значимос & категорий \\
\hline 1-й уровень значимости & 2-й уровень значимости \\
\hline Помощь ^ЮАям & Исполнение гражАанского, служебного \\
\hline Отношение к труду & $\Delta \circ \wedge\ulcorner a$ \\
\hline Исполнение гражАанского, служебного Аолга & Черты ^ичности \\
\hline
\end{tabular}


БАРЫКИНА А. И.

ПРЕДСТАВЛЕНИЯ О ПОНЯТИИ «СЛУЖЕНИЕ» ПРЕДСТАВИТЕЛЕЙ РАЗЛИЧНЫХ ПРОФЕССИОНАЛЬНЫХ ГРУПП

РосСИЙСКИЙ пСИХологИЧЕСКИЙ ЖУРнАл, 2020, Т. 17, № 3, 44-59. doi: 10.21702/rpj.2020.3.4

ПСИхОЛОГИЯ ТРУДА

Анализ показал, что госслужащие чаще всего определяли понятие служения как «деятельность на благо общества», "участие в улучшении условий жизни людей», "ответственный подход к выполнению стоящих передо мной задач», "упрощение получения государственных услуг», отнесенные к категории «помощь людям» (39\% высказываний). Под служением они также понимали возможность «приносить пользу людям, обществу без цели личного обогащения», «работу на благо народа», персональные усилия по улучшению жизни народа («мои усилия направлены на улучшение жизни граждан»), личное отношение к работе («мое отношение к работе, которую я выполняю ответственно и добросовестно») и т. д. (категория «отношение к труду»).

Особое место в сознании государственных служащих, согласно результатам опроса, принадлежит определениям понятия служения, отнесенным к контент-аналитической категории «исполнение гражданского, служебного долга» (22\% высказываний). Результаты математического анализа показали, что отсутствуют статистически значимые различия между лингвистическими единицами этой группы и выражениями, относящимися к категориям «помощь людям» и «отношение к труду» (по критерию $\chi^{2}$ Пирсона, при $p<0,05$ ).

Вместе с тем статистическая разница не выявлена между лингвистическими единицами, принадлежащими к категории «исполнение гражданского, служебного долга», и лексическими составляющими контент-аналитической категории «черты личности», которые существенно реже в понимании госслужащих определяют понятие «служение» (по критерию $\chi^{2}$ Пирсона, $\mathrm{p}<0,05)$.

По мнению некоторых экспертов-госслужащих, служение следует понимать как «преданность работе», «профессионализм в своем деле...», а субъектом служения считать «человека слова и дела». Логично предположить, что обладание определенными личными чертами на фоне позитивного отношения к работе и при наличии компетенций, необходимых для успешного решения профессиональных задач, могло бы являться своеобразным психологическим ресурсом, который позволяет субъекту профессиональной деятельности исполнять свой гражданский и служебный долг и помогать окружающим. Но полученные от госслужащих данные позволяют интерпретировать служение, прежде всего, как персональную, личностно значимую активность работника, направленную на достижение общественно полезного результата. Такими активностями являются мотивированные определенным отношением помощь окружающим и исполнение долга, хотя последние можно также считать результатом сознательности и активности сотрудника. Применительно к труду государственных служащих и сама активность, деятельность, и ее результат выражаются в «защите прав и свобод человека и гражданина» (Федеральный закон от 27 июля 2004 г. № 79-ФЗ О государственной..., 2004; Федеральный закон от 27 мая 2003 г. № 58-Ф3 «О системе..., 2003; Christensen \& Opstrup, 2018), заботе об их безопасности, создании условий для культурного развития и роста экономического благосостояния.

В сфере социальной защиты населения госслужащие участвуют в разработке, управлении и реализации программ, направленных на социальную защиту материнства и детства, занимаются демографической политикой, оказывают помощь, содействие гражданам в связи с возрастом, состоянием здоровья, социальным положением, недостаточной обеспеченностью средствами существования. Госслужащие оказывают социальную помощь (социальную защиту, социальное обеспечение) как нуждающимся социальным группам, так и конкретным семьям или людям. Часто она проявляется в форме обслуживания больных и престарелых, 
БАРЫКИНА А. И.

ПРЕДСТАВЛЕНИЯ О ПОНЯТИИ «СЛУЖЕНИЕ» ПРЕДСТАВИТЕЛЕЙ РАЗЛИЧНЫХ ПРОФЕССИОНАЛЬНЫХ ГРУПП

Российский психологИчЕский жУРнАл, 2020, Т. 17, № 3, 44-59. doi: 10.21702/rpj.2020.3.4

Психология трудА

заботы о детях, как адресная социальная помощь малоимущим, предоставление им льгот при решении жизненных проблем питания, здравоохранения, образования в виде пенсий, пособий, предоставления материальной помощи и т. д. В сфере культуры госслужащие организуют работу с детьми и молодежью, выявляют и поддерживают таланты, помогают людям искусства творить и продвигать свои произведения, поддерживают индустрию и предприятия.

Таким образом, анализ показал, что госслужащие под служением понимают помощь людям, отношение к труду, исполнение гражданского, служебного долга, т. е. персональную, личностно значимую деятельность работника, направленную на достижение общественно полезного результата при соблюдении приоритета прав и свобод человека и гражданина, закрепленную профессиональными должностными обязанностями.

\section{Анализ представлений о понятии «служение» военнослужащих}

Анализ показал, что доминантную позицию в иерархии представлений о понятии служения военнослужащих ( $\mathrm{n}=28)$ занимают лингвистические единицы, отнесенные к категориям «исполнение гражданского, служебного долга» (45\% высказываний) и «отношение к труду» (29\% высказываний) (табл. 1; рис. 1).

Анализ частоты встречаемости лингвистических единиц в рамках категорий «исполнение гражданского, служебного долга», «отношение к труду», «помощь другим людям», «черты личности» и «богослужение» показал, что между этими категориями существуют статистически значимые различия (по критерию $\chi^{2}$ Пирсона, при $p<0,05$ ). Так, вышеуказанные категории были условно разделены на 3 уровня. К 1-му уровню отнесены категории, с которыми эксперты более всего соотносят понятие «служение», а к 3-му уровню-менее всего. Между категориями 1-го, 2-го и 3-го уровней иерархии существуют статистически значимые различия в частоте отнесения к понятию «служение» конкретных лингвистических единиц $\left(\chi^{2}=6,452\right.$; $\chi^{2}=5,543$, при $\left.p<0,05\right)$. Между категориями внутри каждого уровня статистически значимые различия отсутствуют (табл. 3).

Таблица 3

Структура представлений военнослужащих о понятии «служение» ( $n=28)$

Уровни значимости категорий

1-й уровень значимости

Исполнение гражданского, служебного Аолга

Отношение к труау 2-й уровень значимости

3-й уровень значимости

Помощь ^юАям

Отношение к труду

Помощь ^ЮАям
Черты ^ичности

Богослужение

Примечание: $p<0,05$. 
БАРЫКИНА А. И.

ПРЕДСТАВЛЕНИЯ О ПОНЯТИИ «СЛУЖЕНИЕ» ПРЕДСТАВИТЕЛЕЙ РАЗЛИЧНЫХ ПРОФЕССИОНАЛЬНЫХ ГРУПП

РосСИЙСКИЙ пСИХологИЧЕСКИЙ ЖУРнАл, 2020, Т. 17, № 3, 44-59. doi: 10.21702/rpj.2020.3.4

ПСИХОЛОГИЯ ТРУДА

Анализ показал, что в 45 \% понятие «служение» раскрывается военнослужащими через категорию «исполнение гражданского, служебного долга», т. е. через принятые на себя договорные и добровольные моральные обязательства (Щипаков, 2017). Например, военнослужащими о служении давались такие определения: «выполнение поставленных служебно-боевых задач»; "оказание помощи, польза государству»; "верность Отчизне»; "служить на благо Родине»; "верность воинскому долгу»; "выполнение воинского долга по защите Родины»; «выполнение кодекса русского офицера»; "неукоснительное выполнение своих обязанностей во благо государства»; "посвящение себя делу по защите интересов страны»; "защищать свою Родину»; "...защита своей Родины, мирное небо над головой»; "верность Отчизне, Родине». Другими словами, военнослужащие в своих ответах ставят знак равенства между анализируемым понятием служения и воинской службой, защитой государственных интересов.

При этом нельзя не учитывать данные ученых (Britt, Adler, \& Castro, 2006; Castro \& Hassan, 2016), что специфика и условия военной службы могут влиять на психическое здоровье и благополучие военнослужащих. В этой связи значимы результаты настоящего исследования, что военнослужащие понимают служение через категорию «отношение к труду» (29\% высказываний): «отдавая себя, все свои силы, не щадя своей жизни положить души на алтарь Отечества» и др.

В п. 1 Статьи 59 «Конституции Российской Федерации», принятой всенародным голосованием 04.07.2020 г., указывается, что «Защита Отечества является долгом и обязанностью гражданина Российской Федерации», причем исключительно важной и чрезвычайно почетной. Осознание значимости военной службы вызывает у военнослужащих чувства «гордости» и «nатриотизма», желание «не щадя своей жизни, положить душу на алтарь Отечества», «честно и добросовестно служить, работать на благо страны, для укрепления нашего государства», «посвятить себя делу по защите интересов страны», которые, в свою очередь, начинают играть роль мотивов эффективной деятельности.

Мы разделяем мнение В. Я. Гожикова, что именно восприятие военной службы как почетной обязанности обусловливает особое отношение к процессу ее несения, т. е. как к чему-то очень важному: социокультурный и ценностно-смысловой императив служения (в формате военно-профессионального становления курсантов) проявляется в том, что военнослужащие как активные субъекты «не могут мыслить себя без ценностного отношения к офицерской службе, определяющей основания жизнедеятельности и являющейся системообразующим компонентом их личностно-профессиональной идентичности» (Гожиков, 2017, с. 64).

Таким образом, результаты исследования дают основания предполагать, что некоторая часть выборки усматривает связь между служением и эмоционально-ценностным отношением к деятельности, поскольку определяет понятие «служение», используя формулировки, отнесенные к категории «отношение к труду». Более того, один из экспертов предложил следующую дефиницию: «служение - это такой тип отношения человека к своей деятельности, при котором он ощущает себя ответственным, обязанным добросовестно выполнять свою работу, испытывает гордость».

Анализ также показал, что частота использования лингвистических единиц военнослужащими о понятии служения, отнесенных к категориям «помощь людям», «черты личности» и «богослужение», оказалась самой малочисленной: в 16\%, 7 \%, и 3 \% высказываний соответственно.

Применительно к задаче исследования представлений о понятии служения военнослужащими, значимыми являются результаты изучения Жиляевым (2017) имиджа и составляющих 
БАРЫКИНА А. И.

ПРЕДСТАВЛЕНИЯ О ПОНЯТИИ «СЛУЖЕНИЕ» ПРЕДСТАВИТЕЛЕЙ РАЗЛИЧНЫХ ПРОФЕССИОНАЛЬНЫХ ГРУПП

Российский психологИчЕский жУРнАл, 2020, Т. 17, № 3, 44-59. doi: 10.21702/rpj.2020.3.4

пСихолОгИя ТРУДА

положительного образа российского офицера: по данным автора, 30 \% опрошенных офицеров считают, что истинный офицер должен служить Отечеству, защищать свободу человека и гражданина, охранять общественный порядок и обеспечивать безопасность граждан, приходить на помощь гражданам в трудной ситуации, а значит, должен быть смелым, решительным, мужественным, ответственным, дисциплинированным. Более того, именно такое поведение гражданское население связывает с положительным образом военнослужащего и ожидает от офицера войск национальной гвардии (Жиляев, 2017). Иными словами, автор проводит параллели между понятием «служение» и категориями «помощь людям» и «черты личности»: служить означает помогать Другим, защищать, проявлять мужество и героизм.

Таким образом, анализ показал, что военнослужащие характеризуют «служение» категориями «исполнение гражданского, служебного долга» и «отношение к труду», т. е. понимают служение как долг и обязанность гражданина Российской Федерации по защите Отечества, сопряженный с эмоционально-ценностным отношением к офицерской службе как системообразующим компонентом их личностно-профессиональной идентичности.

\section{Анализ представлений о понятии «служение» пожарных и спасателей МЧС}

Исследование ответов пожарных и спасателей МЧС ( $\mathrm{n}=32)$ показало, что наиболее часто эксперты данной профессиональной категории используют выражения о понятии служения, относящиеся к категориям «черты личности» (36\% высказываний), «помощь людям» (23\% высказываний); «исполнение гражданского, служебного долга» (18\% высказываний), «отношение к труду» (18\% высказываний). Менее всего выражений («служба в церкви», «служба Богу») вошло в категорию «богослужение» (5 \% высказываний) (табл. 1; рис. 1).

\section{Таблица 4}

Структура представлений пожарных и спасателей МчС о понятии «служение» ( $n=32)$

\section{Уровни значимости категорий}

1-й уровень значимости

2-й уровень значимости

Черты ^ичности

Помощь ^ЮАям

Отношение к труду

Богослужение

Исполнение гражАанского, служебного Аолга

Примечание: $p<0,05$. 
БАРЫКИНА А. И.

ПРЕДСТАВЛЕНИЯ О ПОНЯТИИ «СЛУЖЕНИЕ» ПРЕДСТАВИТЕЛЕЙ РАЗЛИЧНЫХ ПРОФЕССИОНАЛЬНЫХ ГРУПП

РосСИЙСКИй пСИХологИЧЕСКИЙ ЖУРнАл, 2020, Т. 17, № 3, 44-59. doi: 10.21702/rpj.2020.3.4

ПСИхОЛОГИЯ ТРУДА

Анализ выявил статистически значимые различия по критерию $\chi^{2}$ Пирсона $\left(\chi^{2}=5,379\right.$; p < 0,05) между категориями «черты личности», «помощь людям», «отношение к труду», «исполнение гражданского, служебного долга» (условно отнесены к 1-му уровню) и категорией «богослужение» (условно отнесена ко 2-му уровню). Таким образом, к 1-му уровню отнесены категории, с которыми эксперты данной группы более всего соотносят понятие «служение», а ко 2-му уровню - менее всего. Между категориями внутри 1-го уровня статистически значимые различия отсутствуют (табл. 4).

Наибольшее количество ответов пожарных и спасателей МЧС о понимании термина «служение» было связано с категорией «черты личности»: «честь», «достоинство», «ответственность», «дисииплина», «отвага», «совесть», «профессионализм». Очевидно, что особенностями служебной деятельности пожарных и спасателей МЧС являются прямые угрозы жизни и здоровью сотрудников и слишком высокая цена профессиональных ошибок. Соответственно, для того, чтобы действовать эффективно, необходимы не только специальные знания, практические умения, но и определенные личностные профессионально важные черты, психические состояния, мотивация, обусловливающие качественную реализацию профессиональных задач по спасению людей и имущества, по оказанию первой помощи пострадавшим, по защите населения при возникновении чрезвычайных ситуаций и пр. (Федеральный закон «О пожарной безопасности»..., 1994). Кроме того, деятельность пожарных и спасателей регламентирована нормативными и уставными документами, которые определяют цели, задачи профессиональной деятельности, функциональные обязанности должностных лиц подразделений, контроль исполнения поставленных задач, права и обязанности служащих, предписывают способы поведения, жесткую субординацию в отношениях участников коллективной деятельности и взаимоотношения между ними.

Также пожарные и спасатели МЧС понимают служение через категорию «помощь людям» (23\% лингвистических единиц): «быть ответственным за жизнь и спокойствие других», «спасать людей», «защищать людей» и др. В 18 \% высказываний экспертов понятие «служение» соотносится с «долгом», «служением Родине», «службой народу», «защитой населения», вошедших в категорию «исполнение гражданского, служебного долга». $18 \%$ ответов представляют сущность понятия «служение» как «труд, работа во имя кого-то или чего-то», "ответственное отношение к служебным обязанностям» и др., отнесены к категории «отношение к труду». Существенную роль в поведении экспертов - пожарных и спасателей МЧС, на наш взгляд, играют высокая моральная ответственность и дисциплинированность, стрессоустойчивость, героическое начало, готовность и способность быстро мобилизоваться, идти на риск, продуманно действовать в условиях многозадачности, возможно, недостатка информации и дефицита времени, отношение к своим обязанностям как социально полезной деятельности и гражданскому, служебному долгу и пр. Вероятно именно поэтому, давая понятие служению, эксперты поставили знак равенства между категориями «черты личности», «помощь людям», «отношение к труду» и «исполнение гражданского, служебного долга» (статистически значимых различий по критерию $\chi^{2}$ Пирсона не выявлено $\left.(p<0,05)\right)$.

Так, анализ показал, что пожарные и спасатели МЧС под служением понимают регламентированную деятельность по спасению жизни людей в условиях чрезвычайных ситуаций, характеризующуюся наличием у человека определенных личностных качеств и эмоционально-ценностным отношением. Наиболее значимыми категориями в представлении пожарных и спасателей МЧС о понятии «служение» являлись категории «черты личности», «помощь людям», «отношение к труду», «исполнение гражданского, служебного долга». 
БАРЫКИНА А. И.

ПРЕДСТАВЛЕНИЯ О ПОНЯТИИ «СЛУЖЕНИЕ» ПРЕДСТАВИТЕЛЕЙ РАЗЛИЧНЫХ ПРОФЕССИОНАЛЬНЫХ ГРУПП

Российский психологИчЕский жУРнАл, 2020, Т. 17, № 3, 44-59. doi: 10.21702/rpj.2020.3.4

пСихолОГИЯ ТРУДА

\section{Выводы}

Таким образом, качественный и количественный анализ категориальных данных позволил установить, что представления экспертов о понятии «служение» имеют некоторые сходства и различия, обусловленные, вероятно, спецификой и содержанием их профессиональной деятельности, личностными характеристиками.

Согласно результатам опроса экспертов и данным статистического анализа, категории «отношение к труду», «исполнение гражданского, служебного долга» и «помощь людям» являются статистически наиболее употребляемыми дефинициями (26\%, $28 \%$ и $26 \%$ лингвистических единиц соответственно) и, как следствие, основными в представлении экспертов о понятии служения (табл. 1).

Остальные категории: «черты личности» (18\% ответов) и «богослужение» (3\% ответов) играют второстепенную роль и существенно реже используются в качестве определения понятия служения.

На основании полученных результатов делается вывод о том, что несмотря на специфику различных сфер деятельности, эксперты (госслужащие, военнослужащие, пожарные и спасатели МЧС) оказались близки в своем понимании служения, с одной стороны, как профессиональной деятельности, направленной на оказание помощи людям, обусловленной эмоционально-ценностным отношением к труду, а с другой - как процесса исполнения гражданского, служебного долга личностью.

Оригинальность и новизна результатов исследования заключаются в расширении пониманий и представлений о служении, в восполнении недостатков информации о феноменологических основах служения как психологической категории и в возможности их использования в практической деятельности психологических служб организаций по морально-психологическому и мотивационному обеспечению служебной деятельности, например, для актуализации мотива служения.

\section{Литература}

Антонова, О. И. (2009). Социальное служение религиозных общностей в современной России: опыт социологического исследования (кандидатская диссертация). Уральская академия государственной службы, Екатеринбург.

Артюхов, И. П., Горбач, Н. А., Бакшеева, С. Л., Большакова, И. А., Жарова, А. В., Лисняк, М. А. и Шерстяных, Д. М. (2012). Экспертные оценки: методология и практика применения. Фундаментальные исследования, 10, 11-15.

Базаров, Т. Ю., Ерофеев, А. К. и Шмелев, А. Г. (2014). Коллективное определение понятия «компетенции»: попытка извлечения смысловых тенденций из размытого экспертного знания. Вестник Московского университета. Серия 14. Психология, 1, 87-102.

Байбородова, Л. В. и Чернявская, А. П. (2018). Методология и методы научного исследования. Москва: Юрайт.

Гожиков, В. Я. (2017). Служение Отечеству как социально-психологический фактор военно-профессионального становления и личностного развития курсантов военных вузов. В А. Г. Караяни, В. Я. Гожиков, С. И. Данилов, А. В. Мымрин (ред.), Психология служения: Материалы межрегиональной научно-практической конференции психологов силовых структур (с. 62-71.) Москва: Военный университет.

Денисенко, В.Н.и Чеботарева, Е. Ю. (2008). Современные психолингвистические методы анализа речевой коммуникации. Москва: РУДН. 
БАРЫКИНА А. И.

ПРЕДСТАВЛЕНИЯ О ПОНЯТИИ «СЛУЖЕНИЕ» ПРЕДСТАВИТЕЛЕЙ РАЗЛИЧНЫХ ПРОФЕССИОНАЛЬНЫХ ГРУПП

РосСИЙСКИй пСИХологИЧЕСКИЙ ЖУРнАл, 2020, Т. 17, № 3, 44-59. doi: 10.21702/rpj.2020.3.4

ПСИХОЛОГИЯ ТРУДА

Дойникова, Н. А. (2006). Социальное служение Православной церкви во второй половине XIX начале XX веков: на материалах Вологодской епархии (кандидатская диссертация). Российская академия государственной службы при Президенте Российской Федерации, Москва.

Жиляев, А. А. (2017). Формирование мотивации служения у военнослужащих войск национальной гвардии Российской Федерации. В А. Г. Караяни, В. Я. Гожиков, С. И. Данилов, А. В. Мымрин (ред.), Психология служения: Материалы межрегиональной научно-практической конференции психологов силовых структур (с. 72-77.) Москва: Военный университет.

Золотухина, Н. Ф. и Смирнова, Т. М. (2013). Идеалы служения и проблемы обслуживания: (Об опыте взаимодействия НКО с библиотеками и организациями инфраструктуры науки и культуры Петербурга). В А. В. Андронов, Ш. С. Жабко (ред.), Сто и один: язык, народ, культура в пространстве библиотеки: Материалы Международной научно-практической конференции (с. 13-14). Санкт-Петербург: Российская нац. библиотека.

Зубанова, С. Г. (2012). Социальное служение волонтера. Москва: Лика.

Зубанова, С. Г. (2013). Социальное служение в России: исторический опыт, теоретические основы, современная практика. Москва: Российский государственный социальный университет.

Зубанова, С. Г., Степанов, И. И., Патюлина, Н. Д. и Рузанова, Н. П. (2013). Социальное служение Русской Православной Церкви: вопросы истории, теории, практики. Москва: Лика.

Карпов, П. Е. (ред.-сост.). (2013). А. А. Юрлов: служение музыке: статьи-воспоминания о музыканте и педагоге. Москва: Спутник+.

Карпова, Г. С., Сочивко, Д. В. и Пастушеня, А. Н. (2019). Экспертная оценка профессионально-личностного роста сотрудников исправительных учреждений в процессе направленного психологического развития их профессиональной компетентности. Прикладная юридическая психология, 3, 90-98.

Краснобаева, Ю. Е. (2013). Понятие «служение» и институт диаконата в раннем христианстве (кандидатская диссертация). Московский государственный университет им. М. В. Ломоносова, Москва.

Кулик, Д. Ю. (2017). Творческий путь К. К. Платонова как пример служения военно-авиационной психологии. В А. Г. Караяни, В. Я. Гожиков, С. И. Данилов, А. В. Мымрин (ред.), Психология служения: Материалы межрегиональной научно-практической конференции психологов силовых структур (с. 310-314). Москва: Военный университет.

Левченко, И. Е. и Черкасова, М. Ф. (сост.). (2013). Социальное служение Русской православной церкви. Екатеринбург: Уральский институт социального образования.

Максименкова, А. С. (2018). Влияние темперамента на упешность учебной деятельности студентов. Вопросы науки и образования, 13, 107-110.

Московичи, С. (1995). Социальное представление: исторический взгляд. Психологический журнал, 16(1), 3-18; 16(2), 3-14.

Мустафина, Л. Ш. (2012). Структура социальных представлений учащейся молодежи о совести (кандидатская диссертация). Институт психологии РАН, Москва.

Панюшкин, В. А. (ред.). (1997). Служенье Истине: Научное наследие Л. Д. Кокорева: сб. ст. Воронеж: Воронежский университет.

Решетняк, Н. А. (2017). Служение словом и слову. В А. Г. Караяни, В. Я. Гожиков, С. И. Данилов, А. В. Мымрин (ред.), Психология служения: Материалы межрегиональной научно-практической конференции психологов силовых структур (с. 279-286). Москва: Военный университет. 
БАРЫКИНА А. И.

ПРЕДСТАВЛЕНИЯ О ПОНЯТИИ «СЛУЖЕНИЕ» ПРЕДСТАВИТЕЛЕЙ РАЗЛИЧНЫХ ПРОФЕССИОНАЛЬНЫХ ГРУПП

Российский психологИчЕский жУРнАл, 2020, Т. 17, № 3, 44-59. doi: 10.21702/rpj.2020.3.4

пСихолОГИЯ ТРУДА

Селиховкин, А. В. (ред.). (2009). Лисино. 200 лет служения лесам России. Санкт-Петербург: СПбГАТА.

Степанов, И. И. (2012). Социальное служение Русской Православной Церкви в конце ХІХ начале XX вв. (на примере Рязанской епархии) (кандидатская диссертация). Московский государственный гуманитарный университет им. М. А. Шолохова, Москва.

Стуков, В. И., Осяева, Т. Н. и Шашкина, М. Н. (сост.). (2013). Их жизнь - служение науке: биографический справочник о докторах наук и профессорах Саратовского государственного аграрного университета имени Н. И. Вавилова: 1913-2013. Саратов: Саратовский ГАУ.

Субаева, О. Н. (2004). Социальное служение как исторический феномен: 1701-2001 г2. (докторская диссертация). Московский государственный социальный университет, Москва.

Устиненко, В.Б. (2008). Социальное служение религиозных организаций в контексте социальной политики современной России: на примере Санкт-Петербурга (кандидатская диссертация). Российская академия государственной службы при Президенте Российской Федерации, Москва.

Федеральный закон «О пожарной безопасности» от 21.12.1994 № 69-Ф3 (последняя редакция) (1994). КонсультантПлюс. Доступ 06 августа 2020, источник http://www.consultant. ru/document/cons doc LAW 5438/

Федеральный закон от 27 июля 2004 г. № 79-Ф3 О государственной гражданской службе Российской Федерации (2004). Российская газета, 0(3539). Доступ 06 августа 2020, источник https://rg.ru/2004/07/31/gossluzhba-dok.html

Федеральный закон от 27 мая 2003 г. № 58-Ф3 «О системе государственной службы Российской Федерации» (2003). Российская газета, 0(3217). Доступ 06 августа 2020, источник https:// rg.ru/2003/05/30/sluzhba-dok.html

Щипаков, В. Э. (2017). Мотивация служения - основа подготовки по специальности «психология служебной деятельности». В А. Г. Караяни, В. Я. Гожиков, С. И. Данилов, А. В. Мымрин (ред.), Психология служения: Материалы межрегиональной научно-практической конференции психологов силовых структур (с. 78-85). Москва: Военный университет.

Barykina, A., \& Shutova, N. (2018). The motive of service as a determinant of the psychological stability of the medical worker: statement of the problem. KnE Life Sciences, 4(8), 119-133. doi: $10.18502 / \mathrm{kls} . v 4 i 8.3269$

Benini, A., Chataigner, P., Noumri, N., Parham, N., Sweeney, J., \& Tax, L. (2017). The use of expert judgment in humanitarian analysis - Theory, methods, applications. Geneva, Assessment Capacities Project - ACAPS. Retrieved from https://www.acaps.org/sites/acaps/files/resources/ files/acaps expert judgment - full study august 2017.pdf

Blozen, B. B. (2018). Serving the profession. Retrieved from https://www.myamericannurse.com/ serving-profession/

Britt, T. W., Adler, A. B., \& Castro, C. A. (2006). Military life: The psychology of serving in peace and combat. (Military culture, Vol. 4). Westport, PA: Praeger Security International.

Castro, C. A., \& Hassan, A. M. (2016). Military mental health and combat deployments. In H. S. Friedman (Ed.), Encyclopedia of Mental Health (pp. 137-143). Academic Press. doi: 10.1016/B978-0-12-397045-9.00253-6

Christensen, J. G., \& Opstrup, N. (2018). Bureaucratic dilemmas: Civil servants between political responsiveness and normative constraints. Governance, 31(3), 481-498. doi: 10.1111/gove.12312

Hurst-Wahl, J. (2014). Serving the profession. Retrieved from http://hurstassociates.blogspot. com/2014/03/serving-profession.html 
Khan, F. A. (2017). Serving faith, profession, and community: Fifty years of Imana (1967-2017). Partridge Publishing.

Langsley, D. G. (1989). Serving the public by serving the profession. Interview by Wes Curry. Physician Executive, 15(2), 2-7.

Malik, A. A., Yamamoto, S. S., Souares, A., Malik, Z., \& Sauerborn, R. (2010). Motivational determinants among physicians in Lahore, Pakistan. BMC Health Services Research, 10, 201. doi: $10.1186 / 1472-6963-10-201$

McNeely, J. (n.d.). Serving people is a privilege. Retrieved from https://www.globalrefuge.org/ serving-people-is-a-privilege

Neal, T. M. S., \& Grisso, T. (2014). Assessment practices and expert judgment methods in forensic psychology and psychiatry: An international snapshot. Criminal Justice and Behavior, 41(12), 1406-1421. doi: 10.1177/0093854814548449

Sims, R., \& Openshaw, M. D. (1980). Professional agronomists - solving problems, serving people. Journal of Agronomic Education, 9(1), 97-99. doi: 10.2134/jae.1980.0097

Zondervan-Zwijnenburg, M., van de Schoot-Hubeek, W., Lek, K., Hoijtink, H., \& van de Schoot, R. (2017). Application and evaluation of an expert judgment elicitation procedure for correlations. Frontiers in Psychology, 8, 90. doi: 10.3389/fpsyg.2017.00090 